Dr. Richard Andree from Oklahoma (author of "Selections from Modern Abstract Algebra") will give a course using this book, and Dr. Max Wyman will give one on "Elementary Mathematics from an Advanced Viewpoint". The courses will run for six weeks, concurrently with the regular Summer Session. Fund from the University, the Congress and the Department of Education are being used to provide bursaries which it is hoped will encourage teachers to attend. The bursaries will be worth $\$ 300$ to teachers outside Edmonton, or $\$ 200$ to those living in Edmonton, out of which they will pay the summer school fees and their board and lodging. The Institute will be under my general direction and I shall be glad to supply further information if it is desired.

The general purpose of the Institute is to acquant high school teachers with some of the more modern ideas that are beginning to percolate down to the first-year University level and that probably will find their way eventually even into high school. As a preliminary to a radical revision of the mathematics high school curriculum, it will be necessary to educate the teachers themselves, and the proposed Summer Institute is a step in this direction.

\title{
E.S. Keeping
}

\section{NEWS FROM THE DEPARTMENTS}

University of Alberta: Dr. W.J. Bruce from the Oregon College of Education, has been appointed to the staff. Mr. A. S. B. Holland, from New Zealand, has been appointed as a lecturer in the Calgary branch of the University.

Miss Z.M. Hyduk has been awarded the degree of M.Sc. for a thesis on "The Method of Darboux" (for Asymptotic Expansions). This work was done under the direction of Dr. M. Wyman.

Dr. Wyman gave a paper on "The Asymptotic Behavior of the Laurent Coefficients"at a Symposium on Asymptotic Expansions held in November at Pomona College, Claremont, California. On his way to California, Dr. W yman stopped off at Vancouver to give a mathematics talk at U.B.C.

For the first time for several years, the Department has entered a team in the Putnam Competition.

Assumption University of Windsor: This year the third year of the honours course in pure and applied Mathematics was introduced. The enrollment in the first three years of this course is fifteen.

Five graduates of the Mathematics major program returned for the extra year after graduation, required for specialist stand- 
ing at the Ontario College of Education.

University of British Columbia: The following people have joined our staff: John Abramowich from University of California, Fred Brauer from University of Chicago, Philip Deuel from University of California, Nisar A. Khan from University of Aligarh, Elod Macskasy from University of Budapest, Henryk Minc from University of Edinburgh, Charles Schaller-Kelly from Downing College, Cambridge, H.A. Thurston from University of Bristol, J.V. Whittaker from University of California.

Two members of staff are away on leave during this academic year. Dr. T.E. Hull is at California Institute of Technology, and Dr. R.A. Restrepo is at Stanford University.

Dr. Harry F. Davis has left our staff and is now with the Department of Mathematics, Royal Military College, Kingston, Ontario.

Dr. George E. Cross received his Ph. D. in Mathematics at the October convocation. The supervisor of his thesis was Professor R.D. James, and the External Examiner was Professor R.L. Jeffery. The title of his dissertation is "On the uniqueness of multiple trigonometric series".

McMaster University: Graduate student John G. Taylor is working towards a Ph.D. in the field of topology; Morris Liebovitz is working towards an M.Sc. in the field of topology; Frederick Livingston is working towards an M.Sc. in the field of algebra. All of them are under the supervision of Dr. Banaschewski.

Dr. J.H.H. Chalk attended the Summer Research Institute of the Canadian Mathematical Congress as a visitor. He later gave lectures at the Theory of Numbers Seminar at Notre Dame and also gave a lecture at the International Congress in Edinburgh. N.D. Lane and B. Banaschewski attended the Summer Research Institute of the Canadian Mathematical Congress. D. B. Sumner was an instructor at the Mathematics Seminar for High School Teachers at Lunenburg, N.S.

Dr. W.H. Williams has recently been appointed to the Department. His field is statistics and his special research interest is Sampling Theory.

Université de Montréal: Monsieur Léon LeBlanc a été nommé assistant professeur et Monsieur Gabriel Thierrin a été nommé professeur agrégé. Messieurs Roland Guy et Simon Kochen sont attachés de recherche à titre de boursiers postdoctoraux du Conseil National de Recherches.

Monsieur Jean Ménard a recu le grade de M.Sc. à la colla- 
tion des grades d'octobre 1958 pour une thèse intitulée: "Les modules sur les anneaux de Prlufer et leurs extensions". Monsieur Marc Venne a recu le grade M.Sc. à la collation des grades d'octobre 1958 pour une thèse intitulée: "Sur la hiérarchie finie de Kleene et ses analogies avec les hierarchies de Lusin et de Borel".

Les professeurs Geoffrey Fox et Abel Gauthier ont tous deux assisté au dernier Congrès International de Mathématiques à Edimbourg.

Memorial University of Newfoundland: Two new members have been added to our staff this year in the rank of Assistant Professor: A.E. Fekete, who has recently obtained his M.Sc. Degree from the University of Ottawa, and J.P. Carragher, B.A., B.A.I., from Trinity College, Dublin.

University of Ottawa: The Computing Centre started its operations in mid-July. The Centre is under the direction of Dr. A.C. Smith who is assistadkiby a newly appointed as sistant professor J.L. Howland, Ph.D. (Harvard), formerly chief mathematician with Computing Devices of Canada. The Centre employs two programmers and two operators, and is equipped with an I. B.M. 650 computer. The establishment of the Computing Centre has been made possible through support from the National Research Council, the Defense Research Board and the Department of Mines and Technical Surveys.

Professor J.T. Duprat has resigned and taken a new position at Laval University. New sessional lecturers are: W. Heikkila, Ph.D. (Toronto); Mrs. J. Mainwood, B.Sc. (London); Mrs. M. Helfenstein, B.Sc. (Alberta).

Dr. Helfenstein was at the Summer Research Institute in Kingston. He directed the work of $\mathrm{Mr}$. A. Fekete who completed his thesis for the M.Sc. degree, "Problems on prolongation of geodesics". Mr. Fekete has been appointed assistant professor at the Memorial University.

A new project for high-school teachers in sciences and mathematics was introduced in the summer. For teachers of mathematics the project was supported by a grant from International Nickel Company and by the Canadian Mathematical Congress. Under this plan teachers work under the guidance of professors, either assisting in research or preparing essays on special topics relevant to high-school teaching.

Queen's University: Two new appointments have been made to the staff, Dr. Hale Trotter and Dr. Robert R. D. Kemp. Dr. Trotter graduated from Queen's and obtained his $\mathrm{Ph} . \mathrm{D}$. at Princeton. Dr. Kemp graduated from McMaster and obtained his Ph. D. 
at M.I.T.

Dr. Amemiya is continuing his Post-Doctoral Fellowship, working with Professor Halperin.

University of Western Ontario: The following are additions to the staff of the Department of Mathematics and Astronomy: Dr. Harvey Arnold (Assistant Professor), Dr. W.A. O'N. Waugh (Assistant Professor).

The name of the Department has been altered to "Department of Pure and Applied Mathematics and Astronomy". By tine end of the current academic year the Department will be offer ing separate major programs in Statistics, Actuarial Mathematics, Pure Mathematics, Applied Mathematics, and Astronomy.

\section{RESUMES DE THESES DE DOCTORAT}

Olgierd BIBERSTEIN, Géométrie differentielle Minkowskienne, thè se présentée à $1^{\prime}$ Université de Montréal, septembre 1957 (professeur I. Fary, directeur)

La première partie de ce travail est consacrée à la géométrie différentielle du plan de Minkowski. On introduit une famille de repères affines dits "minkowskiens" analogues aux repères orthonormés dans le plan euclidien. Le "repère de Frenet" d'une courbe est un repère minkowskien convenable; on démontre des "formules de Frenet" qui, outre une courbure $k$ définie autrement par M. Busemann, mettent en jeu l'invariant $\bar{K}=K \lambda^{-1}$ dit "anti-courbure", $\lambda$ désignant la courbure de "l'isopérimétrice" du même auteur. La considération des repères minkowskiens et de l'anti-courbure éclaircit le role important (resté peut-être un peu mystérieux jusqu'ici) joué en géométrie minkowskienne par l'isopérimétrice. Les théorèmes les plus connus de la géomètrie différentielle du plan euclidien se généralisent facilement; en outre un théoréme euclidien apparaît le plus souvent comme spécialisant deux théorèmes minkowskiens distincts.

Dans la deuxième partie consacrée à la géométrie minkowskienne à trois dimensions intervient, à titre fondamental, une "première transformation de courbure" dont le déterminant est la "courbure gaussienne" (autre que celle de M. Busemann) de la surface. Les "déplacements infinitésimaux" d'un repère dit "semi-minkowskien" et d'un repère dit "minkowskien" sont car- 